\title{
Variations on a Motive: Hamsun and Tammsaare ${ }^{1}$
}

\author{
ANNELI KÕVAMEES
}

\begin{abstract}
In 1935 Ma armastasin sakslast (I Loved a German) was published. In 1928 Victoria (1898) by Knut Hamsun (1859-1952) was published in Estonian. The first was written and the second translated by A. H. Tammsaare (18781940). Parallels between these two authors have been most often discussed in connection with Pan (1894) and Kõrboja peremees (The Master of Kõrboja, 1922). Both authors have earned their canonical position in literature thanks to the novels Markens Grøde (Growth of the Soil) (1917), in the case of Hamsun, and Tõde ja õigus (Truth and Justice, I-V, 1926-1933) in the case of Tammsaare. These novels have been "sorted out" to be included in the canon, while Ma armastasin sakslast and Victoria have not received as much attention. In both novels love is the central theme - in Hamsun's novel the main characters are the miller's son Johannes and the landlord's daughter Victoria, and in Tammsaare's novel the student Oskar and a baron's granddaughter, Erika. This article examines the connections between Hamsun and Tammsaare by analysing the novels Victoria and $M a$ armastasin sakslast, discussing among others the motive that has been widely used in world literature, namely the (archetypical) story of lovers Romeo and Juliet by Shakespeare. Both novels can be considered as variations on that motive as Tammsaare, for example, adds the social aspect, so that the archetypical love story set in the Republic of Estonia enables him to discuss topics essential to him. In the article the main emphasis is on Tammsaare's novel.
\end{abstract}

Keywords: A. H. Tammsaare; Knut Hamsun; love story; motive; variation

\section{Introduction}

Estonian writer A. H. Tammsaare (1878-1940) and Norwegian writer Knut Hamsun (1859-1952) are canonical authors who have a firm position in the literary canon of Estonian and Norwegian literature, respectively. ${ }^{2}$ Hamsun

1 This study was supported by the Estonian Ministry of Education and Research (IUT 18-4), and by the European Union through the European Regional Development Fund (Centre of Excellence in Estonian Studies).

2 Both writers used pseudonyms taken after their childhood homes: Tammsaare-North was a farm in Järvamaa county and Hamsund the estate on the island Hamarøy. Hamsun had intended to adopt the name Hamsund but when the printer omitted the final ' $d$ ' then he adopted the name Hamsun instead (Room 2010: 219). 
has been said to be "one of the most influential and innovative literary stylists of the past hundred years" (Ferguson 1987: 422). He was awarded the Nobel Prize in literature in 1920 for his monumental Markens Grøde (Growth of the Soil, 1917). However, his position is somewhat tainted due to the fact that he became notorious as a Nazi-sympathiser. The name of Tammsaare does not evoke problematic issues. His magnum opus, Tõde ja õigus (Truth and Justice, I-V, 1926-1933) has been named the Estonian core text and he has been seen as the author creating the nation. There is a firm connection between Tammsaare and the myth of Estonianness (Annus 2000: 10).

Markens Grøde and Tõde ja õigus have been "sorted out" to be included in the canon, while Ma armastasin sakslast ${ }^{3}$ (I Loved a German) (1935) by Tammsaare and Victoria (1898) by Hamsun have not received as much attention. Although, in recent years Tammsaare's novel has received wider attention: a film for television was released in 1998 (director Ain Prosa), dramatizations of the novel premiered in Kuressaare City Theatre in 2008 (director Raivo Trass) and in Tallinn City Theatre in 2009 (director Elmo Nüganen). The novel was the subject of a special seminar organised by the Under and Tuglas Literature Centre of the Estonian Academy of Sciences in 2006, followed by the collection of articles in 2013. The novel has been interpreted in a more versatile manner compared to the reception in the 1930s when the national aspect was in the foreground (see Kõvamees 2008). This article examines the connections between Hamsun and Tammsaare by analysing the novels Victoria and $\mathrm{Ma}$ armastasin sakslast, while the emphasis is on the latter.

\section{Hamsun and Tammsaare: Some Literary Connections}

First of all, translations should be mentioned. Tammsaare has translated ${ }^{4}$ Svermere (Dreamers, 1904) into Estonian under the title Unistaja (1918), published in the newspaper Uus Päevaleht. The translation has been described as

3 The novel has been translated into German (Ich liebte eine Deutsche, 1977, translated by Edmund Hunnius), Latvian (Es mìlēju vācu meiteni, 1974, translated by Jānis Žigurs), Russian (Романы: хозяин усадьбы Кырбоя. Я любил немку. Новый нечистый из пекла, 1968, translated by Nora Javorskaja, Olga Nael, A. Sokolov) and English (I Loved a German, 2018, translated by Christopher Moseley) Estonian Literature Centre).

4 Tammsaare was not proficient in Norwegian, therefore his translation was based on a translation. It has been noted that "Translation of quality literature in Estonia gained ground at the beginning of the $20^{\text {th }}$ century. Clearly, there were no specific translation theories used in Estonia at that time, therefore, the translations were first made via another language. However, already in the 1920s this practice was given up and the translations from the original language became more valuable” (Kvell 2015: 83). 
"correct and beautiful" noting that Tammsaare has sensed Hamsun better than Johan Järv whose translation was published in 1930 (Rebane 2003: 172). Tammsaare's translation of Victoria was first published in the magazine Elu (No. 18 in 1924 and No. 6 in 1925) and as a book in 1928 (Rebane 2003: 173). ${ }^{5}$

It has been noted that "the same sweet-painful sadness" characterizes both Tammsaare and Hamsun (Tillemann 1939: 780). Hamsun's influences have been noticed especially in connection with Pan (1894) and the novel Körboja peremees (The Master of Kõrboja, 1922). ${ }^{6}$ Estonian writer and journalist Albert Kivikas noted several similarities between these novels stating that Kõrboja peremees is an Estonianized and Tammsaare-like version of Hamsun (Kivikas 1923: 73). Hilve Rebane has noted that "the rhythms of Kõrboja peremees are downright Hamsun-like” (Rebane 2003: 170). There are motives ${ }^{7}$ taken from $P a n$ but these have been used to create a more complex novel both in the sense of structure as well as ethical problems (Haug 2010: 22, see also Annist 1943: 190). The same applies to Tammsaare's short story Kärbes (The Fly, 1917) and Hamsun's Just an ordinary fly of average size (1897), although the end moral is the same in both stories - a human being is not and should not be a fly (Rebane 2003: 178). Estonian writer and literary critic Friedebert Tuglas has noted a similar function of a crippled character called Kata in Tammsaare's short story Üle piiri (Over the Border, 1910) as has poor Minute in Hamsun's Mysterier (Mysteries, 1892). Both allegorize the character's unhealthy self that has grown puny and crippled (Tuglas 1918: 47). It has been noted that creating texts out of texts is more characteristic of Tammsaare than usually believed. It may be said that since the beginning of the 1920s, Tammsaare methodically sets his works into world literature, creating there "his individual intertextual honeycomb", which meant, figuratively speaking, growing over Hamsun who had interested him during his student years (Haug 2010: 21-22).

While the majority of intertextual connections between Tammsaare and Hamsun belong to the earlier period, there are motives to be found also in Tammsaare's later works. For example, both $M a$ armastasin sakslast and Hamsun's Sult (Hunger, 1890) have a young starving writer who writes about his love story. Tammsaare's main character Oskar starves both physically and mentally; he also lacks love (Rebane 2003: 168). It has been noted that in $M a$

5 Excerpts from the novel had been published in newspapers in 1910 (Rebane 2003: 173). There are also translations by Richard Janno $(1938,1962,2016)$ and Henrik Sepamaa $(1986,1995)$. It is worth mentioning here that an Estonian feature film based on the novel premiered in 1994 (director Jüri Sillart).

6 About the novel see e.g. Vaino 2009: 5.

7 The issue has been more thoroughly discussed in Haug 2010. 
armastasin sakslast the approach to hunger is completely different because of its psychological depth (Plath 2013: 60).

Ulrike Plath has set a wider background stating that the psychological structure of $\mathrm{Ma}$ armastasin sakslast is better understood in comparison with other hunger novels, e.g. Wilhelm Raabe's Der Hungerpastor (1864) and Doris Lessing's Hunger (1953) in addition to Hamsun's Sult. In Hamsun's and Lessing's novel hunger is the symptom of the culture of the industrial age and of colonial hatred for humans. In these cases, hunger acts as a progressive force. The main characters satisfy their inner desires for food, love and life as well as possible. Oskar's hunger is much more complicated than the hunger of Hamsun's main character because he does not know how to actually accept learning possibilities, food and love offered to him. Although eating is in both novels associated with love, the restraint of desires is a much more important line of development in Tammsaare's novel. Hunger is a synonym of both life and death drive (Plath 2013: 58).

There are other connections to be found. Similarly to Edvarda in Pan, Erika, the main female character in Ma armastasin sakslast, also wishes to be compromised by her loved one and when it does not happen, is disappointed. Oskar disappears like lieutenant Glahn. In Pan the white crescent moon predicts death as in Tammsaare's novel moon light, snow and Erika's memory of her mother as something in white have that role. Pondering over truths and lies of love is also Hamsun-like (the Alley of Lies), which occurs already in Tammsaare's student novels (Pikad sammud (Long Steps, 1908)) (Rebane 2003: 170). Parallels can also be found between Victoria and the story of Indrek and Ramilda in the second volume of Tõde ja õigus. Ma armastasin sakslast has been said to be "first and foremost a love novel à la Hamsun's Victoria" (Alekõrs 1940: 149).

\section{Ma armastasin sakslast and Victoria: Comparative Observations}

$\mathrm{Ma}$ armastasin sakslast can be seen as the essence of Tammsaare's articles published in the 1930s where he discussed national issues, youth, fraternities and parvenus, etc. It has been noted that the polemical relationships between Estonian national culture and Baltic German culture, ideological and economic growing pains of the Estonian Republic, urbanization, the mentality of the parvenu and problems related to abandoning one's nationality are critically observed. The novel is one of the most delicate reflections of the modernisation of the Estonian society at the beginning of the $20^{\text {th }}$ century. At the same time the novel is one of the greatest love stories of Estonian and also world 
literature. In that novel everything, including life, is sacrificed in the name of love (Hinrikus, Undusk 2013: 7).

The plan to bring together an Estonian and a Baltic German has resulted in a deep psychological novel, not just an ordinary love novel (Palgi 1938: 31). Ma armastasin sakslast has been called a flaming and perfect Estonian love novel (Undusk 1992: 719), maybe even the best Estonian love novel of all times (Undusk 2013: 253), and Tammsaare has been called a great master of the psychology of love (Puhvel 1981: 326). Victoria is also one of the most famous and most beautiful love stories (Saluäär 2008: 343); in that novel one could find some of the most poetic depictions of love, e.g. "What, then, is love? A wind whispering among the roses - no, a yellow phosphorescence in the blood. A dance macabre in which even the oldest and frailest hearts are obliged to join. It is like the marguerite which opens wide as night draws on, and like the anemone which closes at a breath and dies at a touch" (Hamsun s.a.: 17). "Asked what love is, some reply: It is only a wind whispering among the roses and dying away. But often it is an inviolable seal that endures for life, endures till death. God has fashioned it of many kinds and seen it endure or perish" (Hamsun s.a.: 63). Hamsun concentrates on the love theme while Tammsaare discusses also other issues.

Tammsaare has used a literary device in which the novel is presented as a found manuscript. The novel begins with the preface from the author with initials A. H. T. who notes that he is only the editor of the novel while the real author is the man called Oskar whose whereabouts are unknown. In the preface Tammsaare analyses the manuscript and also the position and role of the author stating for example "The reason my name is used as the author of the book is caused on one hand by the economic, on the other hand by literary-artistic reasons. The first were understandably emphasised by those who wished to gain profit, the others by me personally. Namely, I thought that when the book is published under the real name or under the pseudonym of the lost young man, then people definitely start to search for prototypes, and when many are looking, then they will find something. That way a large amount of literary science would be produced which would take all the attention away from literature and diminish the interest towards the book. People after all have that kind of strange characteristic that they are much more interested in the Carrara marble or the place of finding of some clay than figures made from that marble or modelled from the clay. People have been fascinated by the logic that a piece of art is explained and understood when it is known from which it is made and from where the material is taken" (Tammsaare 1984: 7-8, here and henceforth my translation - A.K.). In that statement one could see Tammsaare's reaction to the one-sided approach to literature which concentrated primarily on finding 
the prototypes of his characters in Tõde ja õigus while literary aspects were left in the background. Ironic criticism can be detected in the sentence "By using my name as the author we expected to receive at least the ordinary reception" (Tammsaare 1984: 9). The name of the author carries certain meanings and can be seen as a trademark. Tammsaare is aware of his position in the 1930s Estonia and as an acknowledged author, one could expect at least "the ordinary reception".

The preface is followed by the story written by Oskar, which forms the main body of the novel. The novel is written in the first-person and at the end there is a letter from the main female character Erika where events are seen from her perspective. The letter from the main female character also ends the novel by Hamsun, while the majority of the novel is told from Johannes's perspective. Thus, in both novels the main story is told from the male character's point of view while female characters are given a voice in the end. This allows the reader to follow the ideas and thoughts of male characters without knowing the other party's point of view, which is revealed only in the end. For example, one of the peaks of the novel Ma armastasin sakslast is the episode with Erika's briefcase, which she has with her in one meeting with Oskar. This episode has been said to be the best in the novel reaching the height of world literature (Romaan aadli prestiizhist 1936). Oskar does not understand the significance of the briefcase, which is later revealed in Erika's letter. Erika had been ready to run away with Oskar, meaning she was ready to compromise herself if that was the only way they could get married. Thus, she was carrying the briefcase with the items for her "wedding night". She had also obtained a promise from her grandfather that he would take her back no matter what happened during that escape. This is Erika's big secret, which changes the course of events and is revealed in her letter.

The culmination of the love story is the situation where characters are entangled in secrets. This creates a barrier, which has been seen to mark the psychological and/or social borders neither of them can cross. At the moment the secret is left untold, the fate of the llovers is sealed. The walk with "Erika's secret" is the culmination of the novel followed by the fatal change in the plot. The secret is used as a metaphor through which a seemingly accidental detail turns out to be fatal (Vaino 2011: 56). Similarly, in Shakespeare's Romeo and Juliet one of the secrets leading to the tragic end is the potion which is meant to be the saviour of young lovers but as the important message does not reach Romeo, it turns out to be the opposite.

Secrets between characters are typical of Tammsaare's work where ordinary and everyday items or situations can obtain a special meaning, fatal or sacral dimension. A secret is a key feature of many characters. For example, Tiina in Tõde ja õigus nearly identifies with her secret as the other character carrying a 
painful secret is Indrek. In Körboja peremees the main female character Anna has a secret. Secrets themselves are not something mystical but, influenced by these, characters start to act strangely and irrationally. As a result, they suffer and cause suffering to others. For reasons unknown even to themselves they rather suffer than reveal their secrets (Vaino 2011: 45-49). Erika reveals her secret in her letter, which Oskar receives after her death ${ }^{8}$ according to her wish, and then it is too late and the letter presumably leads to Oskar's suicide.

In that letter Erika also expresses her love by saying "I believe I loved you even before I met you, only I did not know it is you that I love" (Tammsaare 1984: 181). Unlike Erika who reveals her feelings in the letter, Victoria expresses her feelings before (see Hamsun s.a.: 23). Similarly to Oskar, Johannes receives Victoria's letter after her death where she "blames herself and her nature for the failure of the love affair, thus confirming Johannes's presentation of her at the beginning of the novel” (Žagar 2009: 59). Although Hamsun gives his female character a 'voice', which is exceptional, as his novels are usually told from a male character's point of view (see e.g. McFarlane 1956: 590-591), he clearly lays blame on the weaker sex. Contrary to Hamsun, in Tammsaare's novel the matter is much more complicated. Although Erika blames herself, she also says that "We were like two foolish kids who considered a thousand things in the past, present and future but not our love" (Tammsaare 1984: 193). Thus, in the end Erika writes about 'our love', there are two participants in the story.

Erika's letter in the end has been found to be one of the most ravishing and deepest episodes among Tammsaare's works (Paukson 1940: 310). The motive of a letter can also be found in the second volume of Tõde ja oigus where Indrek receives letters from Ramilda, while the last letter reaches him after her death (see also Vaino 2011: 110). Letters are the key and power of romantic love. Everything that is absent or unspoken between a man and a woman is put in letters, full of honesty and longing (Undusk 2013: 261).

Writing is an important activity in both novels as female characters write letters and male characters write novels. It is noteworthy that in both novels the main characters address each other formally, an aspect lost in English translation as the language does not differ between formal and informal 'you', the distinction both the Norwegian language and the Estonian language make. When Victoria and Johannes meet again after several years, Johannes accidentally addresses her informally and is startled (Hamsun 2016: 16). That line has been omitted in the English translation. Only in her final words in her

8 Victoria's and Erika's letters are written from the threshold of death: "When you read this letter, I am already dead" (Hamsun s.a.: 75); "I am writing these lines because I feel the nearness of death" (Tammsaare 1984: 180). 
letter Victoria addresses Johannes informally (Hamsun 2016: 104). Erika uses the formal 'you' throughout her letter.

As mentioned above, white is a significant colour in both novels. ${ }^{9}$ Oskar imagines Erika in white: "I imagined her in white and felt how I started to love that white as some kind of distant memory or gh ost. I started to love her entirely differently from the way I had loved until now" (Tammsaare 1984: 65 , my emphasis - A.K.). Moreover, white is the colour dividing two different worlds - Erika's mother who is remembered wearing white and Oskar's mother who says that one cannot wear white as it gets dirty very quickly (Tammsaare 1984: 65) - the world of Baltic German life of leisurely and the world of working peasants collide. White colour characterizes Erika, a girl with white hair, her mother and also her grandfather "whose bony hand was so white that it seemed to gleam in the dimness just like his hair" (Tammsaare 1984: 93). ${ }^{10}$

A woman in white is also to be found in Hamsun's Victoria, for example Johannes writes: "In one of the garden walks stands Victoria; she is alone, dressed in white, she is twenty. There she stands, taller than the tallest rosebush, gazing over the water, towards the woods, towards the somnolent distant mountains - a white spirit in the midst of the green garden" (Hamsun s.a.: 32, my emphasis - A.K). In his fantasies Johannes sees her wearing white and Victoria lives in a white castle. It is noteworthy that a castle associates with both Victoria and Erika. Victoria lives in a castle but is later forced to marry a wealthy man because her father has lost his fortune. Erika on the other hand has already lost her castle as due to the land reform in Estonia in 1919 Baltic Germans lost their manors. Although Erika says she does not remember the days when her grandfather was lord of the manor, Oskar still sees her as a noblewoman and places her in the role of a princess. Symbolically, when they meet for the last time in the park, Erika runs towards the castle ${ }^{11}$ "as there would be her home" (Tammsaare 1984: 171). Erika and Victoria remain in the constraints of their past as in both novels father figures direct the lives of female characters: Victoria is forced to marry by her father and because of her grandfather's disapproval, Erika does not marry Oskar.

In the interpretations of the novel Oskar has usually been seen as the one responsible for the failure of the love story. He can be seen as a typically Tammsaare-like male character who has not succeeded in life (see e.g. Undusk,

9 About other colours and their symbolic value in Victoria see e.g. Eddy 1976: 159 and Rebane 1996.

10 See also Undusk 2013: 308.

11 Although it is not specified in the novel, the episode can be placed in Kadrioru park in Tallinn, so the castle is Kadriorg Palace. 
KÕVAMEES

R. 2013: 82; a man who is a failure has been seen as characteristic of the Estonian tradition on the whole (Haug 2010: 19). Although the humility of Oskar can be simply a sign of love, not a sign of his national inferiority, e.g. when Oskar falls to his knees and embraces Erika's knees or kisses her hands, such episodes can be seen as "activating prejudices derived by sociological models" (Undusk 2013: 242). ${ }^{12}$ Oskar and Erika are not usually seen as two young people loving each other but first of all as a Baltic German (former) ruler and an Estonian peasant.

Oskar can also be characterised by his "inability to act" (Buttry 1982: 99), which has been found to describe Hamsun's characters. Oskar, like several Tammsaare's male characters (first of all Indrek), has been found to be a great masochist, someone whose mind is open to failure (Mutt 2014: 823-824). "The Weltschmerz expressed by Hamlet is no foreign sentiment [...] to the poet Johannes in Victoria" (Buttry 1982: 104). Hamsun's characters "ruin their relationships in order to escape from fearful responsibilities and risks. [...] Fear of the unknown direction their relationship, once established, might take dictates the passivity of many a Hamsun's hero, and sometimes even engenders negative action, as when Glahn and Johannes reject Edvarda and Victoria. For the Hamsun hero, it is much easier to imagine a perfect ending in one's mind. [...] Their illusions are so beautiful that they sense the impossibility of reality's ever equalling their imagined bliss. Therefore, they prefer to remain in the safe world of their fantasy rather than to venture out into the riskfilled "real" world" (Buttry 1982: 109). Oskar has been found to love Erika according to the rules of courtly love, which has a precondition that the object is unobtainable. Until one can be certain of the barrier, all the efforts are made to win the Lady's love but when the Lady actually offers herself to the knight, he draws back in dismay (Annus 2002: 581-582). On the other hand, Oskar's readiness to give up everything for Erika (Tammsaare 1984: 170) has been seen as an uncompromising manifest of devotion, which is an evidence of archaic, mythical love experienced with the depth of the Old Testament. His words are definitely one of the most sublime in Estonian literature and rare in the context of world literature (Undusk 2013: 302).

Either way it seems that Tammsaare does not have a happy conception of love. In his interpretation love has a traumatic effect on people. Great love is often such a strong feeling that his characters cannot endure it (Vaino 2016:

12 Similarly, Johannes thinks "He would be her servant and slave and sweep a path before her with his shoulders. And he would kiss her delicate shoes and pull her carriage and stock her stove with firewood on cold days, stock her stove with firewood tipped with gold [...]" (Hamsun s.a.: 14). 
24). The majority of Tammsaare's love stories have an unhappy ending. This is part of his so-called love philosophy in the centre of which is a Tammsaarelike paradox: if there is happy love, then it is unhappy love (Vaino 2016: 26). ${ }^{13}$ "One cannot equate love with happiness, mental balance nor with pleasure. Two young people have to pay with great sufferings and eventually with their lives for their short episode. Reaching a dead end and total mental unbalance, they search for oblivion [...] and the greatest oblivion in their minds is death. Love is therefore the prelude of death. That pessimistic point of view is not unique for Tammsaare. The novel offers one of the most interesting and versatilely developed variations of that great topic in his works" (Salu 1956: 226). Therefore, it may be said that in Ma armastasin sakslast Tammsaare varies a motive central in his works or Tammsaare has always written to a greater or lesser extent the same opus. Ramilda in the second and Kristi in the third volume of Tõde ja õigus, Erika in Ma armastasin sakslast are all variations of the same invariant. There are similarities between male characters in Tammsaare's student year short stories and Indrek in Tõde ja õigus and also Oskar in $\mathrm{Ma}$ armastasin sakslast (Mutt 2014: 816-817).

In the end $\mathrm{Ma}$ armastasin sakslast is the best Estonian love novel of all times. If the marriage fails then not only because the lovers cannot overcome the social obstacles but also because Tammsaare is not interested in "marriage as utopia"14 but in the "love as utopia". In the name of love marriage is sacrificed. If marriage does not fail, then love would fail. Marriage would bring new problems and ground the story of pure love. To keep love, Tammsaare has to prevent it becoming something else than only love. He does it radically by ending the story when love is flaming, furthermore, he removes both characters so we would not have the temptation to imagine them having some other future. This has been one of the poetic principles of love stories throughout ages: in order to keep love, it is necessary to avoid it becoming down-to-earth. ${ }^{15}$ Therefore, true love can only be a hindered love. Tammsaare has chosen as an obstacle the prejudices of the Baltic class society, which were still present in the Republic of Estonia. Class and national restrictions have been one of the most typical obstacles in love stories but in Tammsaare's case it is more of a tool than a social problem in need of a solution (Undusk 2013: 254). The same applies to Hamsun's Victoria as it has been noted that "Such a class barrier is a somewhat

13 About Tammsaare's love conception see also Sillaots 1935.

14 See Undusk 2007.

15 This is the romantic model of love according to which love cannot have the continuance, the ecstatic passion would become ashes unless the author lets the lovers die or finishes the novel at the right time (Annus 2016: 149) 
KÕVAMEES

artificial device for literature of so a late period, but it serves here as a poetic symbol" (Eddy 1976: 161).

\title{
Conclusion
}

Although Victoria and Ma armastasin sakslast do not belong to the canonical works of Hamsun and Tammsaare, these novels discuss issues and use techniques essential to these canonical authors. Tammsaare was influenced by Hamsun, there are similar motives and structural patterns; however, he certainly did not copy Hamsun. The motives have been used as a soil to create a more complex novel both in the sense of structure as well as ethical problems.

At the same time both authors have adopted a motive that has been widely used in world literature, namely the (archetypical) story of lovers - Romeo and Juliet by Shakespeare. ${ }^{16}$ Both novels can be considered as variations on that motive, as Tammsaare adds the social aspect, so that the archetypical love story set in the Republic of Estonia enables him to discuss topics related to the national identity, the ideological and economic growing pains of the Estonian Republic. The novel may be interpreted as Romeo and Juliet set in the Republic of Estonia. Instead of real social barriers, the obstacles in both Victoria and $\mathrm{Ma}$ armastasin sakslast are more of a mental nature. It may be said that although these novels do not belong to the canonical works of Hamsun and Tammsaare, by variating a well-known motive they connect with world literature. In the case of Tammsaare, the novel is clearly seen to belong to world literature. Variation does not mean copying or in the worst-case scenario plagiarism. On the contrary, if the reader recognises the used motive, then the variation intertwines with the previous ones creating a particular interlacing of motives and themes. Each variation enriches the motive and thus literature.

\author{
Anneli Kõvamees \\ anneli.kovamees@tlu.ee \\ Tallinna Ülikool \\ Humanitaarteaduste instituut \\ Narva mnt 29 \\ 10120 Tallinn \\ EESTI / ESTONIA
}

\footnotetext{
16 About the motive in connection with the legend of Barbara von Tiesenhusen see Kreem, Lukas 2008.
} 
Variations on a Motive: Hamsun and Tammsaare

\section{References}

Alekõrs, R. 1940. A. H. Tammsaare teoste lõpplahendused. - Eesti Kirjandus, 4, 145163.

Annist, A. 1943. Järelsõna. - A. H. Tammsaare Kõrboja peremees. Tallinn: Eesti Riiklik Kirjastus, 181-191.

Annus, E. 2000. Kirjanduskaanon ja rahvuslik identiteet. - Keel ja Kirjandus, 1, 10-17.

Annus, E. 2002. Kubjas ja korporant: armastusest ja rahvuslikust moraalist. - Looming, 4, 576-587.

Annus, E. 2016. Armastusest: tõerežiimid, kultuurilised kujutelmad ja kehaline ilmakogemus. - Methis, Vol. 14, No. 17/18, 145-160.

Buttry, D. 1982. The Passive Personality: Hamsun's Hamlets. - Symposium: A Quarterly Journal in Modern Literatures, Vol. 36, Issue 2, 99-114.

Eddy, B. D. 1976. Hamsun's Victoria and Munch's Livfrisen: Variations on a Theme. Scandinavian Studies, Vol. 48, No. 2, 156-168.

Estonian Literature Centre. - http://www.estlit.ee/elis/?cmd=writer\&id=39986\& $\operatorname{grp}=x 2(11.12 .2018)$.

Ferguson, R. 1987. Enigma. The Life of Knut Hamsun. New York: Farrar, Straus \& Giroux.

Hamsun, K. s.a. Victoria. Translated by Oliver Stallybrass. https://08554441813363063636. googlegroups.com/attach/1b822cbfbe336235/Victoria-A Love Story - Knut Hamsun.pdf?part=4\&vt=ANaJVrE5WKX00uSUWJFuUsgKvULjL9hCRKxx5 zN0iEe4GbRFoKw6R2XnbBKPchG-Vh253JnUhXyJdhWodLuqYwXBDT2fB6 0KMCxGRKXz8gK5S0KMkxE4QkI (13.06.2017).

Hamsun, K. 2016. Victoria. Translated by Richard Janno. Tallinn: Varrak.

Haug, T. 2010. A. H. T. lahkumine Koitjärvelt. Lapse sünd „Kõrboja peremehes“. T. Haug, Klassikute lahkumine. Tallinn: Eesti Keele Sihtasutus, 18-38.

Hinrikus, M., Undusk, J. 2013. Saateks. - M. Hinrikus, J. Undusk, eds., Armastus ja sotsioloogia. A. H. Tammsaare romaan „Ma armastasin sakslast“. Tallinn: Underi ja Tuglase Kirjanduskeskus, 7-10.

Kivikas, A. 1923. A. H. Tammsaare „Kõrboja peremees“. - Looming, 1, 72-74.

Kreem, Juhan, Lukas, Liina 2008. „Romeo ja Julia“ Liivimaa moodi? Barbara von Tiesenhauseni legend: ajalooline tagapõhi ja kirjanduslikud variatsioonid. - Keel ja Kirjandus, 3, 156-177.

Kõvamees, A. 2008. Eestlase endapildi mõjud kriitikale. - R. Veidemann, M. Kirme, eds., Kriitika diskursus: minevik ja tänapäev. Tallinna Ülikooli toimetised Humaniora A28. Tallinn: Tallinna Ülikooli kirjastus, 147-160.

Kvell, S. 2015. Tammsaare as a translator. - K. Suurmäe, ed., Our Tammsaare. Meeting Book with the Writer. Tallinn: A. H. Tammsaare Museum, A. H. Tammsaare Museum in Vargamäe, 83-86.

McFarlane, J. W. 1956. The Whisper of the Blood: A Study of Knut Hamsun's Early Novels. - Modern Language Association, Vol. 71, No. 4, 563-594.

Mutt, M. 2014. Oskar kui meie aja kangelane. „Ma armastasin sakslast“ üle lugedes. Looming, 6, 815-828. 
KÕVAMEES

Palgi, D. 1938. Kunstlikust võttest A. H. Tammsaare romaanide ehituses. - Eesti Kirjandus, 1, 20-33.

Paukson, H. 1940. Tammsaare looming linnulennult. - Varamu, 3, 303-311.

Plath, U. 2013. Näljast ja näljapsühholoogiast A. H. Tammsaare romaanis „Ma armastasin sakslast“. - M. Hinrikus, J. Undusk, eds., Armastus ja sotsioloogia. A. H. Tammsaare romaan „Ma armastasin sakslast“. Tallinn: Underi ja Tuglase Kirjanduskeskus, 50-71.

Puhvel, H. 1981. A. H. Tammsaare. - E. Sõgel, ed., Eesti kirjanduse ajalugu. Vol. 4. Tallinn: Eesti Raamat, 286-342.

Rebane, H. 1996. Armastuse poeesia ja inimvahekordade ilu. - Kultuurileht, 23.02.

Rebane, H. 2003. Knut Hamsuni looming Eestis. - H. Rebane, Uhke põhjamaine. Esseid ja uurimusi Põhjamaade kirjandusest. Tallinn: Underi ja Tuglase Kirjanduskeskus, $167-181$

Romaan aadli prestiizhist. 1936. A. H. Tammsaare: Ma armastasin sakslast. - Vaba Maa, 02.05.

Room, A. 2010. Dictionary of Pseudonyms: 13,000 Assumed Names and Their Origins. $5^{\text {th }}$ ed. Jefferson, N.C.: McFarland \& Co.

Salu, H. 1956. A. H. Tammsaare romaan „Ma armastasin sakslast“. - A. H. Tammsaare, Ma armastasin sakslast. Stockholm: Vaba Eesti, 225-230.

Saluäär, A. 2008. Knut Hamsun, „Maa õnnistus“ ja eesti kirjandus. - A. Saluäär, Põhjamaadest ja Eestist. Kirjutisi 1987-2008. Tallinn: Eesti Keele Sihtasutus, 343-347.

Sillaots, M. 1935. Armastus kui probleem eesti iseseisvusaegses proosakirjanduses. Eesti Kirjandus, 6, 275-284.

Tammsaare, A. H. 1984. Ma armastasin sakslast. Tallinn: Eesti Raamat.

Tillemann, E. 1939. Knut Hamsunile mõteldes. - Varamu, 7, 777-782.

Tuglas, F. 1918. A. H. Tammsaare. Kriitiline essee. Tartu: Odamees.

Undusk, J. 1992. Saksa-eesti kirjandussuhete tüpoloogia. - Keel ja Kirjandus, 12, 709-725.

Undusk, J. 2007. Die Ehe als Utopie: Einfuhrung in ein literarisches Motiv. - M. Garle, Hrsg., Literaturbeziehungen zwischen Deutschbalten, Esten und Letten. Zwolf Beitrage zum 7. Baltischen Seminar 1995. (Schriftenreihe Baltische Seminare, Bd. 5.). Luneburg: Verlag Carl-Schirren-Gesellschaft, 185-201.

Undusk, J. 2013. Armastus ja sotsioloogia. Sissevaade Tammsaare omailma. - M. Hinrikus, J. Undusk, eds., Armastus ja sotsioloogia. A. H. Tammsaare romaan „Ma armastasin sakslast“. Tallinn: Underi ja Tuglase Kirjanduskeskus, 242-342.

Undusk, R. 2013. Romaani „Ma armastasin sakslast“ vormist ja struktuurist. M. Hinrikus, J. Undusk, eds., Armastus ja sotsioloogia. A. H. Tammsaare romaan „Ma armastasin sakslast". Tallinn: Underi ja Tuglase Kirjanduskeskus, 82-91.

Vaino, M. 2009. The Master of Kõrboja. - 10 Books form Estonia, No. 2. Estonian Literature Centre, p. 5. http://www.estlit.ee/centre/uploads/catalogues/ kataloog_2009.pdf

Vaino, M. 2011. Irratsionaalsuse poeetika A. H. Tammsaare loomingus. Tallinn: TLÜ.

Vaino, M. 2016. Tammsaare irratsionaalsuse poeetika. Tallinn: Eesti Keele Sihtasutus.

Žagar, M. 2009. Knut Hamsun. The Dark Side of Literary Brilliance. Seattle: University of Washington Press. 